\title{
LOCATION OF UNWANTED FACILITIES IN PRAGUE: NIMBY IN PUBLIC ADMINISTRATION HIERARCHY
}

\section{Martin Dlouhý, Tomáš Hudeček*}

\begin{abstract}
The paper investigates how the problem of NIMBY (Not-In-My-Back-Yard) related to the location of unwanted facilities is dealt in a hierarchically organized city. The conventional view of NIMBY is based on two premises: first, that locally unwanted facilities are essential to achieve an important societal benefit and realize the public good; second, that selfish opposition of local community prevents the realization of that societal good. The NIMBY effect is studied as a conflict between the City of Prague and its city districts. The official documents of the Prague City Council and of the Prague City Assembly were searched to find examples of decisions on the location of unwanted facilities. The documents search was concentrated on five selected facilities: municipal waste dumps, services for the homeless, services for drug users, regulation of gambling facilities, and the system of parking zones. In the documents, the authors identified five types of approaches to NIMBY that are called financial compensation, fair distribution, local autonomy, gradual problem shifting, and consultation/cooperation. It was observed that city districts, lower level of public administration, behave as guardians of local interests if they communicate with a higher level of public administration, a guardian of global interests. As local politicians depend on their local voters, it is not surprising that they prefer local interests to global ones. This naturally creates an internal policy conflict in the city that is divided into smaller units.
\end{abstract}

Keywords: NIMBY, LULUs, Prague, public administration, negative externality JEL Classification: R53, H49

\section{Introduction}

The objective of democratic national, regional or municipal governments should be to serve citizens, which means, among others, to provide public services and finance or regulate various types of private services for population. Public services can provide public good for the whole population or they can be oriented towards specific disadvantaged population groups. At first sight, it seems that public services fulfilling societal objectives should be welcomed by local communities. However, in the reality, location of some types of facilities can often lead to conflict situations. For example the location of facilities providing social services for homeless people or facilities providing services for drug users in the community

* Martin Dlouhý, Faculty of Informatics and Statistics, University of Economics in Prague, Prague, Czech Republic (dlouhy@vse.cz);

Tomáš Hudeček, Faculty of Science, Department of Applied Geoinformatics and Cartography, Charles University, Prague, Czech Republic (hudecek@dr.com) and Czech Technical University in Prague, The Masaryk Institute of Advanced Studies, Prague, Czech Republic.

This work was supported by the Czech Science Foundation under Project No. 16-01821S, and by the institutional support for the long-term development of science and research at the Faculty of Informatics and Statistics, University of Economics in Prague. 
is felt as negative experience and people object to opening of such type of facilities in their neighbourhood. If such facilities were to be located elsewhere, the same people would have been in favour. This observation is described in the literature as NIMBY (Not In My Back Yard) or LULUs (Locally Unwanted Land Uses).

The term NIMBY has been regularly used in the newspapers and scientific literature since the 1980s (e.g. Livezey, 1980; Hall, 1981; Mitchell and Carson, 1986; Davis, 1986). By the SCOPUS database search we were able to find 533 articles with the term NIMBY in the title, abstract or keywords (accessed on 15 January, 2016). The conventional view of NIMBY is based on two premises: first, that locally unwanted facilities (waste incinerators, shelters for homeless, airport, highways, etc.) are essential to achieve an important societal benefits and realize the public good; second, that selfish opposition of local community prevents the realization of that societal good (Lake, 1993). In such situation, the solution to NIMBY lies in overcoming irrationality, changing selfish attitudes, improving regulatory mechanism, offering some kind compensation to local community. Critics of the NIMBY response argue that as a result, essential projects have become impossible to site, thus restricting or delaying economic development and technically superior solutions, for example to problems such as hazardous waste disposal (Kraft and Clary, 1991).

However, it can be argued that unwanted facilities are not needed by the society but rather by business. In this characterization, NIMBY represents rather a barrier not to societal benefit but to selfish goals of business. NIMBY is thus an expression of people's needs and fears (Lake, 1993; Hager and Haddad, 2015). According to Wolsink (2007), the validity of the NIMBY theory is questionable and the idea that opposition is due to egoist NIMBY-type motives has become a great burden to the handling of critical attitudes. The problem is the imprecise and simplistic way the NIMBY concept is used by academics and policy makers (Wolsink, 2007). We suppose that in practice, both alternatives of NIMBY can be probably found. The question is whether this alternative description of NIMBY as barrier to pure business goals with no societal benefits may be classified as NIMBY at all.

The economic theory describes a situation similar to NIMBY as a problem of negative externality. A positive or negative externality is said to be present whenever the well-being of a consumer or the production possibilities of a firm are directly affected by actions of another agent in the economy (e.g. Mas-Colell et al., 1995; Samuelson and Nordhaus 1995). The key problem related to NIMBY lies in the discrepancy between geographically dispersed societal benefits and locally concentrated costs that usually have a form of negative externality. To maximize their utility local residents will be in favour of establishing an unwanted facility, but not in their neighbourhood in order to minimize the costs. Such a choice of optimal strategy by all local communities ends up in the situation that unwanted facilities will not be opened anywhere. Why do local residents so often actively protest? Mobilization is facilitated by the high cost perceived to be imposed on the local community by the unwanted facility, the relatively low cost of protesting, and the relatively high probability of success (Mitchell and Carson, 1986).

In some cases, it can be observed how the opposition to unwanted facilities evolved from a location-specific NIMBY approach into a broader policy critique of the government (e.g. Johnson, 2013). The goals of NIMBY actors expand from opposing unwanted facilities in their backyards to campaigning against locating such facilities anywhere. This is referred to as NIABY (Not In Anybody's Back Yard). As industrialization intensifies across the globe, 
local populations worldwide are mobilizing to protest environmental threats to their communities. Often, contrary to the negative stereotype of NIMBY, these movements achieve lasting change beyond the particular siting controversy. This is true across regions, types of political system, and levels of economic development (Hager and Haddad, 2015).

The discrepancy between global and local interests may also occur at different levels of public administration: national government versus regional governments, regional government versus cities and municipalities, city versus city districts. As local politicians directly depend on their local voters, it is not surprising that the lower level of public administration hierarchy, bearing the burden of local cost, is in opposition to a higher level of public administration collecting dispersed societal benefits. Hence the NIMBY effect is not limited only to traditional external actors as citizens, NGOs, communities on the one side, and business on the other side. Because we talk about public administration led by politicians, NIMBY is not limited only to the substance of the problem but it includes politics, too. The first objective of this paper is to investigate how the problem of NIMBY is dealt in the hierarchically organized municipal practice. We will study it as a conflict between the City of Prague representing global interests of the city, and city districts representing local interests of communities. The conceptual model of the NIMBY effect within the city hierarchy is suggested in Figure 1. Social problems (e.g. homelessness), ecological problems, housing projects or various economic activities lead to siting of public or private facilities that are unwanted by local population. The problem of NIMBY arises and the local politicians dependent on the local voters become the NIMBY advocates in relation with the higher level of city government. The need to cope with a problem necessitates formulating policy or action plan that leads to cooperation or conflict between the City and city districts. Such municipal policy, to be successful, must address both the practical solution of the problem and the response to NIMBY. Drug policy may, for example, include new low threshold facilities. The NIMBY circle is closed.

\section{Figure 1 | Conceptual Model of the NIMBY Conflict within City Hierarchy}

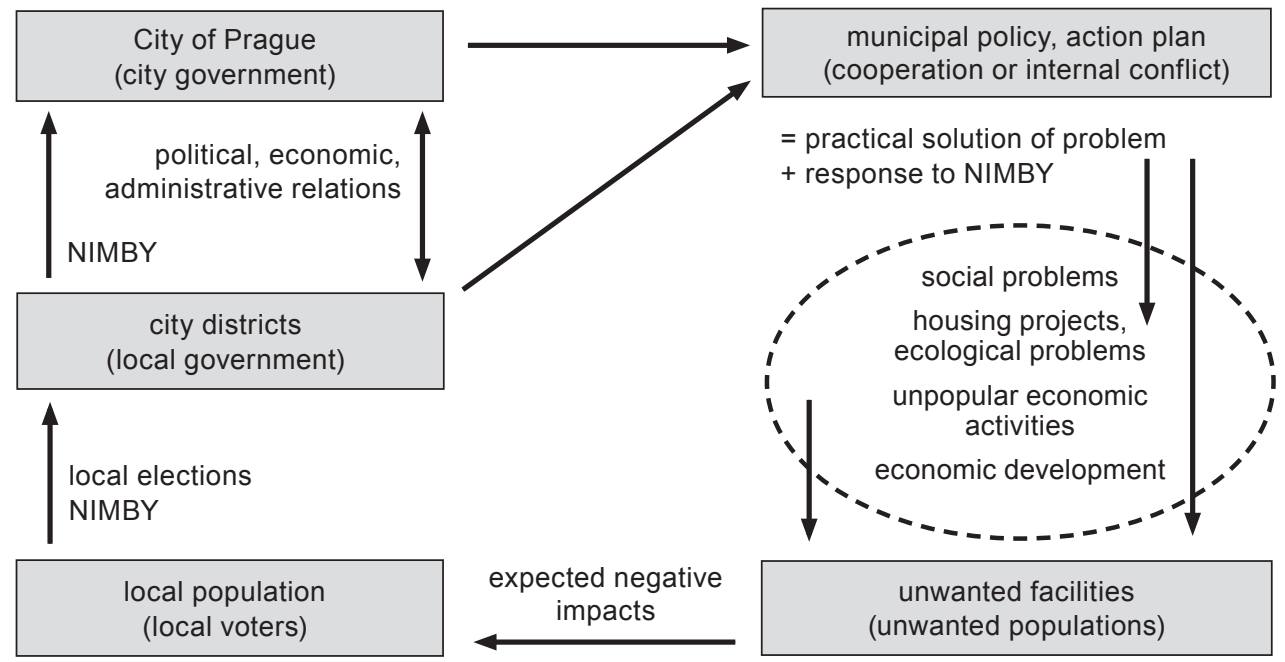

Source: Author 
In this paper, we will study how the City of Prague representing global interests of the city, and its city districts representing local communities deal with the problem of NIMBY. The first objective of the paper is to find the municipal policies that are used by the City of Prague and the second objective is to try to classify these policy approaches to overcoming NIMBY between the city and the city districts into specific categories.

\section{Methods}

The objective is to investigate the practice of dealing with NIMBY effect in the City of Prague ("Praha" in Czech), the capital of the Czech Republic. The City of Prague has a public administrative structure of three tiers. The highest tier is the City of Prague itself represented by the elected Prague City Assembly and the Magistrate of the City of Prague. Since 1990, the city has been divided into 57 self-governing city districts (Figure 2).

\section{Figure 2 | Map of Prague City Districts}

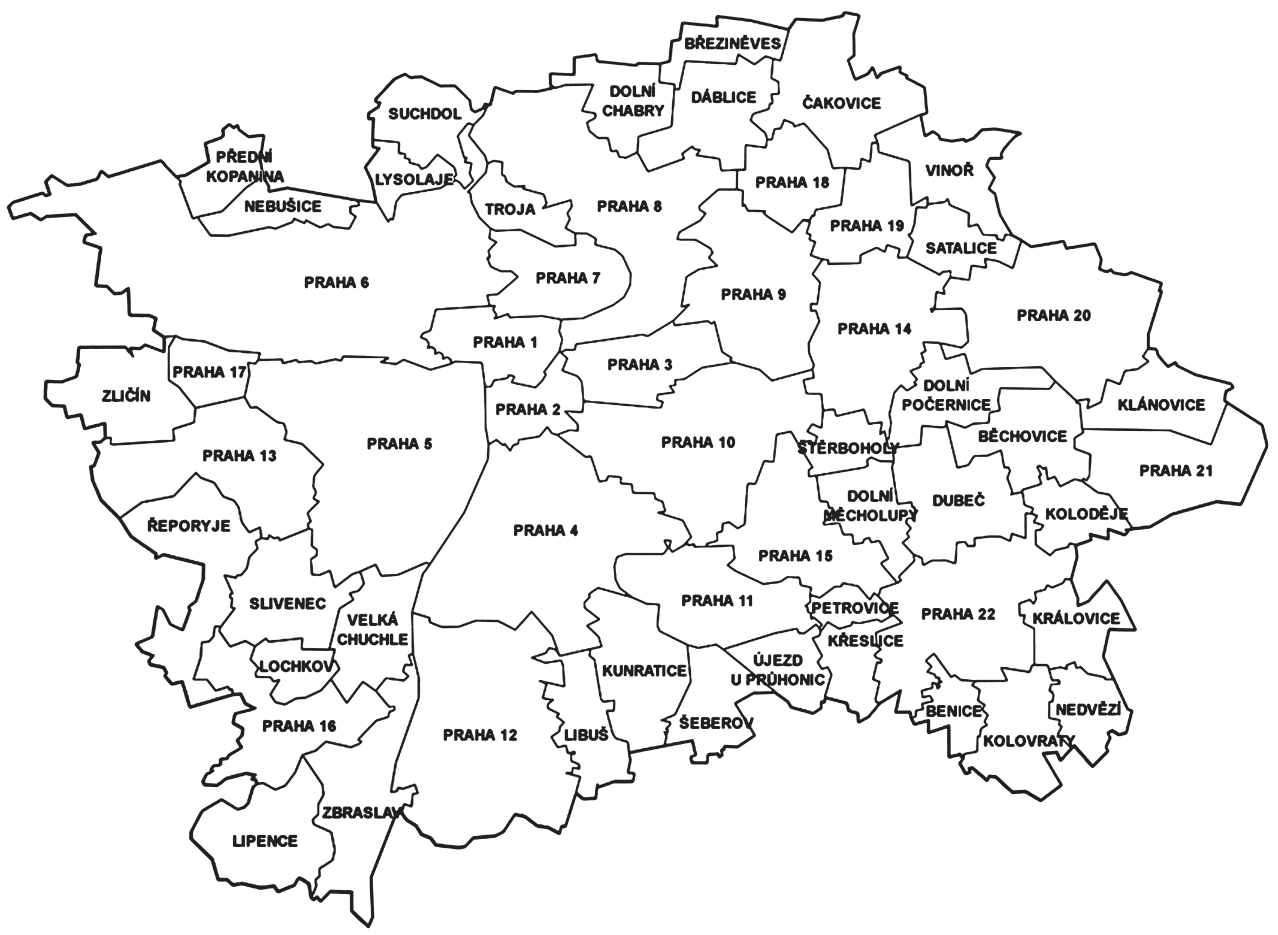

Source: http://www.geoportalpraha.cz/

The city districts differ in the size of population and territory. The city districts Prague 1-22 are the so-called "large" city districts with high numbers of inhabitants and are mostly located in the inner city. The districts Prague 23-57 (these districts use names, not numbers, but for simplicity, we denote them as districts 23-57) are the so-called "small" city districts with much lower numbers of inhabitants and are mostly located in suburban areas. In total, less than $10 \%$ of Prague population live in the city districts Prague 23-57. 
Since 2001, the 57 city districts have been grouped into 22 administrative districts, for state-administration purposes. In this middle tier, one large city district Prague 1-22 in each administrative district has responsibility for providing services of state administration for the entire administrative district. It can be confusing and one has to distinguish whether, for example, by Prague 9 is meant one of the self-governing city districts Prague 1-57 or one of the administrative districts Prague 1-22. In the study, we focus on the relation between the City of Prague and self-governing 57 city districts.

The official documents of the Prague City Council and of the Prague City Assembly were searched to find examples of decisions on the location of facilities with a local negative impact (the documents are available at http://zastupitelstvo.praha.eu/). The documents search have been concentrated on five selected unwanted facilities: municipal waste dumps, social services for the homeless, social services for drug users, regulation of gambling facilities, and the system of residential parking zones, in which the NIMBY effect surprisingly also developed.

\section{Results}

In the documents from the City of Prague that have been searched the authors were able to classify the approaches to NIMBY into five types that will be called financial compensation, fair distribution, local autonomy, gradual problem shifting, and consultation/ cooperation (Table 1).

Table 1 | Summary of Approaches to NIMBY

\begin{tabular}{|l|l|}
\hline Type of Unwanted Facility & \multicolumn{1}{c|}{ Type of Approach } \\
\hline Municipal waste dumps & Financial compensation (City of Prague, 2013) \\
\hline Social services for the homeless & Fair distribution (City of Prague, 2012, 2014d, 2015) \\
\hline Social services for drug users & $\begin{array}{l}\text { Fair distribution (City of Prague, 2014d, 2015) } \\
\text { Consultation/cooperation (City of Prague, 2014a, 2014b) }\end{array}$ \\
\hline Regulation of gambling & $\begin{array}{l}\text { Financial compensation (City of Prague, 2013a) } \\
\text { Local autonomy (City of Prague, 2013b) }\end{array}$ \\
\hline Residential parking zones & Gradual problem shifting (City of Prague, 1995, 2005, 2014e) \\
\hline
\end{tabular}

Source: Author

\subsection{Financial compensation}

One of the alternatives of dealing with the location of unwanted facilities with an expected negative impact on the community certainly is some kind of compensation. In offering compensation, one assumes that the objections of the local community will be overcome if its local residents receive benefits that are sufficient to offset the expected negative impacts (e.g. Kunreuther, Easterling, 1996). The financial compensation can take a number of different forms, either as a monetary payment or as more indirect forms of benefits. The financial compensation is a potentially valuable tool in dealing with the local opposition; however, there is also a risk that the local community may view the compensation as a bribe (Kunreuther, Easterling, 1996). 
For example, three city districts (Brezineves, Dablice, and Dolni Chabry) receive direct subsidy from the City of Prague to compensate the location of municipal waste dumps on their territories (City of Prague, 2013). The city districts also receive various compensations from the company operating the waste dumps. Another example of financial compensation is the regulation of gambling. On the one hand, gambling is seen as an unwanted free-time activity with dangerous negative impacts; on the other hand, the City of Prague and city districts receive specific taxes from gambling facilities that enable them to finance sport activities, culture or social services (e.g. City of Prague, 2013a). If the taxes collected from locally unwanted facilities are used for the benefits of local community, some compromise could be possibly found.

Although not a typical case of NIMBY (if it is NIMBY at all), the conflict of a local community with the Prague Botanical Garden (operated by the City of Prague) provides an interesting example. In 2011, the Prague Botanical Garden planned to enclose an additional territory that was freely accessible at that time. By this measure the Prague Botanical Garden intended to protect its property better, but the new fence interrupted a walking path used by local residents. This plan of the Prague Botanical Garden provoked a disagreement among the local residents and a petition was signed by over 3,000 people. The City District of Prague 8 succeeded in negotiating free admission to the Prague Botanical Garden for the residents in the neighbouring area.

One type of financial compensation is also a political deal. A tough method but very effective. It allows to exchange a wanted facility for an unwanted facility according to the interest of each city district. Such political deals can be realized in terms of cooperation, but at the same time in terms of conflict between the city government and the governments of city districts. As an example, the government of the city could take advantage of an interest of a city district to build a new school and exchange it for its own necessities like shelters for homeless people. We can imagine both extremes: some type of political deals with NIMBY effect can represent even some kind of corruption, and contrary, some of them can become really useful policy agreements if handled carefully by both political representations.

\subsection{Fair distribution}

If it is technically possible, fair distribution of unwanted facilities may be accepted by the city districts as a satisfactory compromise solution. This effort is practiced for example by the New York City (Rose, 1993; Weisberg, 1993). The New York City Charter (Section 203) requires the City Planning Commission to adopt criteria to further the fair distribution of the burdens and benefits associated with city facilities, consistent with community needs for services and efficient and cost effective delivery of services and with due regard for the social and economic impacts of such facilities upon the areas surrounding the sites. The City Planning Commission adopted the Criteria for the Location of City Facilities, which have been in effect since 1991. They are commonly known as the Fair Share criteria because they attempt to foster an equitable distribution of public facilities throughout the city.

The Prague City Council declared that policy of fair distribution of social services with a negative local impact on the communities should be based on three assumptions (City of Prague, 2014d, 2015): 
- The numbers of homeless people and drug users are objective facts and can be estimated to some extent.

- There is no other territory than the territories of the city districts.

- There is no socially and legally acceptable way of forcing the people to leave the city.

If we accept these facts, then the cooperation between the city and city districts is necessary. Fair distribution of social problems is one dimension of solution to the NIMBY effect.

The municipal policy addressing the problem of homelessness is described in its strategic document The Concept of Proposals Addressing the Problem of Homelessness in Prague 2013-2020 (City of Prague, 2012). As an estimate, it is used the number of 4,000 homeless people, from that number 1,500 are the so-called apparent homeless that move around the city. The number of problematic drug users in Prague was estimated at 14,300 in 2013. The municipal drug policy is described in Drug Policy in the City of Prague 2014-2020 (City of Prague, 2014a), Action Plan of Drug Policy 2014-2016 (City of Prague, 2014b), and Annual Report of Drug Policy 2013 (City of Prague, 2014c). To deal with the distribution problem effectively, the level of 22 administrative districts as described above is preferred to 57 self-governing city districts as some city districts are too small. The data on service capacities were prepared by the Department of Health, Social Care and Prevention of the Magistrate of the City of Prague. These types of social services (facilities) are included (City of Prague, 2014d):

- Asylum;

- Low threshold day services centre for the homeless;

- Night shelter for the homeless;

- Low threshold contact centre for the drug users.

Table 2 | Intensity of Negative Impact to Local Community

\begin{tabular}{|l|c|}
\hline \multicolumn{1}{|c|}{ Type of Social Service } & Negative Impact \\
\hline Asylum for mothers and children & 1 \\
\hline Night shelter for the homeless (open only in winter) & 2 \\
\hline Asylum for men & 2 \\
\hline Night shelter for the homeless & 3 \\
\hline Low threshold day service centre & 4 \\
\hline Low threshold contact centre for drug users & 4 \\
\hline
\end{tabular}

Source: City of Prague, 2015

The intensity of negative impact to local community is estimated by numbers 1 to 4 (see Table 2), where value 1 means the lowest negative impact and value 4 means the highest negative impact (City of Prague, 2014d, 2015). The capacity of services is evaluated by the number of beds and the number of contacts and then, the capacities are multiplied by the intensity of negative impact. The total sum of points for each administrative district 
is then used as a measure of fair distribution. The idea to assign points to various types of unwanted facilities is not new, for example Popper (1992) suggested to use such point evaluation of unwanted facilities and then allowing municipalities to trade equivalent projects. In his model, the administrative body would establish point values of facilities and minimum number of points to each city or county, making sure that burden of LULUs was divided equally throughout the region.

Table 3 | Estimation of Negative Impact, Prague Administrative Districts, 2015

\begin{tabular}{|c|c|c|c|}
\hline $\begin{array}{l}\text { Administrative } \\
\text { District }\end{array}$ & Population (2013) & $\begin{array}{c}\text { Total Impact } \\
\text { in Points (2015) }\end{array}$ & $\begin{array}{c}\text { Impact per } 1000 \\
\text { Inhabitants }\end{array}$ \\
\hline Prague 1 & 27,224 & 988 & 36.29 \\
\hline Prague 2 & 43,023 & 542 & 12.60 \\
\hline Prague 3 & 65,459 & 788 & 12.04 \\
\hline Prague 4 & 126,696 & 105 & 0.83 \\
\hline Prague 5 & 76,640 & 850 & 11.09 \\
\hline Prague 6 & 101,930 & 132 & 1.30 \\
\hline Prague 7 & 39,461 & 1,627 & 41.23 \\
\hline Prague 8 & 104,817 & 612 & 5.84 \\
\hline Prague 9 & 46,119 & 386 & 8.37 \\
\hline Prague 10 & 101,079 & 175 & 1.73 \\
\hline Prague 11 & 78,319 & 39 & 0.50 \\
\hline Prague 12 & 59,630 & 69 & 1.16 \\
\hline Prague 13 & 55,531 & 0 & 0.00 \\
\hline Prague 14 & 42,373 & 212 & 5.00 \\
\hline Prague 15 & 41,012 & 200 & 4.88 \\
\hline Prague 16 & 22,136 & 0 & 0.00 \\
\hline Prague 17 & 27,309 & 0 & 0.00 \\
\hline Prague 18 & 23,791 & 0 & 0.00 \\
\hline Prague 19 & 12,037 & 0 & 0.00 \\
\hline Prague 20 & 14,252 & 0 & 0.00 \\
\hline Prague 21 & 16,413 & 0 & 0.00 \\
\hline Prague 22 & 12,989 & 0 & 0.00 \\
\hline Total & $1,138,240$ & 6,725 & 5.91 \\
\hline
\end{tabular}

Sources: City of Prague (2015), own calculations 
The estimation of negative impact to local community is, for the sake of simplicity, calculated for 22 administrative districts, not for 57 city districts (Table 3). In fact, the majority of "small" districts Prague 23-57 that are located in suburban areas have no facilities providing "unwanted" social services. If the estimated total negative impact expressed in points is divided by the district population, the administrative districts with the highest level of "unwanted" social services are Prague 7 and Prague 1 . The administrative districts of Prague 2, Prague 3, and Prague 5 exceed twice the city average. On the other hand, eight of 22 administrative districts have absolutely no "unwanted" social services on their territories. Surely, some types of low threshold services have to be located in such places where problematic clients are. Nevertheless, services like asylums can be located anywhere in the city, thus more fair distribution is achievable.

\subsection{Gradual problem shifting}

A specific example of the conflict between local and global interests is represented by paid residential parking zones. More precisely, by the conflict during the process of establishing paid residential parking zones. Initially, residents of Prague in general do not want to have restricted parking, even if it was in their benefit to have restricted parking around their home. From this point of view, it could be even called as "anti-NIMBY effect". Each person naturally wants to have his or her parking place in front of his or her home, but at the same time each person wants to be free to park anywhere in the city. Thus it was practically impossible for the political representation of the City of Prague to establish the overall system of residential parking in the past. The process of establishing of residential parking zones started on the local level in the very centre of Prague in 1996, on the right-bank part of the city district Prague 1 (City of Prague, 1995). When parking cars moved from the first municipal parking zone to the surrounding city districts, it created tensions there. The NIMBY effect in this situation is not understood as opposition to residential parking zones as such, but as opposition to having the end of residential parking zone near your home, because it becomes the place of parking for those who cannot park inside the residential parking zone.

Table 4 | Residential Parking Zones, 1996-2014

\begin{tabular}{|l|l|c|c|}
\hline Year & \multicolumn{1}{|c|}{ City District } & $\begin{array}{c}\text { Number of Parking } \\
\text { Places }\end{array}$ & Territory in $\mathbf{k m}^{\mathbf{2}}$ \\
\hline $\mathbf{1 9 9 6}$ & Prague 1 - right bank & 7,913 & 3.13 \\
\hline $\mathbf{2 0 0 7}$ & Prague 1 - left bank + Prague 2 & 21,732 & 9.68 \\
\hline $\mathbf{2 0 0 8}$ & Prague 3 (part I) + Prague 7 & 41,723 & 20.20 \\
\hline $\mathbf{2 0 1 1}$ & Prague 3 (part II) & 44,119 & 21.02 \\
\hline
\end{tabular}

Source: Technical Administration of Roadways of the City of Prague (TSK Praha)

Local communities near the parking zone line were unsatisfied that they had problems with parking their own cars and started to lobby for establishing new residential parking zones to move "alien" cars from their territory. The Prague City Assembly approved the concept 
of further development of paid residential parking zones in 2005 (City of Prague, 2005), according to which the rest of Prague 1 and three other city districts should join the parking system till 2008. The left-bank part of Prague 1 and Prague 2 established residential parking zones in 2007, western part of Prague 3 and Prague 7 established parking zones in 2008 (Table 4). The local NIMBY problem was solved, but only by shifting the problems with car parking to others. This process of parking-zone extension led to gradual problem shifting with parking cars and to plans to establish residential parking zones in the rest part of Prague 3, Prague 4, Prague 5, Prague 6, Prague 8, and Prague 9. The overall system of parking regulation, residential parking zones and other rules were not approved until September 2014 by the Prague City Assembly (City of Prague, 2014e).

\subsection{Local autonomy}

Another solution to a conflict between global interests and local interests is to shift the decision making power on the location of unwanted facilities from the higher administrative level to a lower administrative level. In this case it is from the government of the City of Prague to the governments of city districts. A relatively successful example of autonomy is the regulation of gambling. The governments of city districts can regulate the places and opening hours or make a decision to completely prohibit gambling in their territories. Often, the referendum is initiated, either by the city districts or by civic associations. Technically, the decree on lottery regulation in the city is issued by the City of Prague (2013b), however, city districts directly participate in the preparation of this municipal decree and their suggestions are almost always accepted.

Local autonomy in decision making on LULUs can be viewed as implementation of subsidiarity principle, which states in its basic formulation that problems should be dealt with at the most immediate (local) level consistent with their solution. But local autonomy as a solution is not suitable for all types of unwanted facilities, because one possible outcome of such power transfer can lead to a "locally optimal" solution based on just moving the problem from a given district to a neighbouring one. For example, drug users or homeless people may be removed by increased activity of the municipal police in some selected places, but this measure just shifts the problem to some other places. This development is similar to gradual problem shifting, the category that have been already described above.

Petitions against drugs organized by civic associations easily gain popularity among local community. One such petition addressed to the city districts of Prague and to the City of Prague (2014) required to relocate facilities providing services for drug users minimally $2 \mathrm{~km}$ from schools. However, such places do not exist in the densely populated city, with the exception of a few municipal forests or the Prague International Airport.

\subsection{Consultation/Cooperation}

Some kind of consultation, communication or cooperation between the City and the city districts is usually a part of all above mentioned approaches. Here we mean such cases in which consultation, communication, information sharing, participation in planning, public hearings are intended to be the principal method of overcoming the NIMBY effect. Oppositional behaviour recognized as NIMBY is a function of (1) distrust of the project proponents (government, developers); (2) limited information about the problem and 
risks; (3) attitudes that are local and parochial, and which do not consider broader project ramifications; (4) an emotional orientation towards the conflict; and (5) a high level of concern about project risks (Kraft and Clary, 1991). The objective of a higher administrative level is convincing, attitude changing, gaining mutual trust, removing prejudice from unknown. Collaborative approaches to planning should be preferred and technocratic and corporatist based elite decision-making avoided (Wolsink, 2007). In this heterogeneous category one can find a group of various approaches that differ in the intensity of consultation and cooperation that would ideally require further research. In contrast to local-autonomy category, the final decision remains in the hands of a higher administrative level.

The first versions of municipal drug policy documents were rejected by the Prague City Assembly in November 2013, above all due to the strong opposition from the city districts. Subsequent consultations with the city districts in December 2013 and January 2014 where drug policy was explained and the city districts can comment the strategic documents proved useful. According to comments, drug policy was revised and, in March 2014 municipal drug policy was discussed in the City drug commission, City assembly committees and with district drug coordinators. Finally, Drug Policy in the City of Prague 2014-2020 was approved by the Prague City Assembly without any serious objections in March 2014 (City of Prague, 2014a). Action Plan of Drug Policy 2014-2016 was approved in September 2014 (City of Prague, 2014b). Further, it was also agreed that if the City will finance some new facility serving drug users, the city districts will be informed and consulted in advance.

\section{Conclusion}

To study the problem of NIMBY we suggested the conceptual model of the NIMBY effect within the City hierarchy (Figure 1). On the example of public administration hierarchy represented by the City of Prague and its city districts, we investigated the following types of unwanted facilities: services for the homeless, services for drug users, municipal waste dumps, regulation of gambling, and the system of residential parking zones. Services for the homeless or drug users, together with waste dumps, can be seen as public services necessary for the life of the city, so NIMBY can be thus, at least to some extent, perceived as selfish opposition of a local community. Gambling is a totally different case, since no societal benefit, except taxes, is expected. The city administration serves as a regulator that is balancing the interests of community and business. Residential parking zones represent a controversial example in which societal benefit may be questioned.

It was observed that city districts, lower level of public administration, behave as guardians of local interests if they communicate with a higher level of public administration, a guardian of global interests. As local politicians depend on their local voters, it is not so surprising that they prefer local interests to global ones. This naturally creates an internal policy conflict in the City that is divided into smaller administrative units.

Approaches to dealing with NIMBY are classified into five categories: financial compensation, fair distribution, local autonomy, gradual problem shifting, and consultation/ cooperation. The authors are far from claiming that some category of NIMBY solution is universal or better than another category. It needs both further empirical research and literature search to investigate some other approaches that are available for the city government. 


\section{References}

City of Prague (1995). Príprava zóny placeného stánív centrální části hlavního města Prahy (The Preparation of Parking Zones in the Centre of Prague). Prague: Prague City Council, 11 July 1995.

City of Prague (2005). Koncepce dalšího rozvoje zón placeného stání v podmínkách hlavního města Prahy (The Concept of the Further Development of Parking Zones in Prague). Prague: Prague City Assembly, 31 March 2005.

City of Prague (2012). Koncepce návrhů řešení problematiky bezdomovectvív Praze v letech 2013 - 2020 (The Concept of Proposals Addressing the Problem of Homelessness in Prague in the Years 2013 - 2020). Prague: Prague City Assembly, 18 December 2012.

City of Prague (2013). Knávrhu rozpočtu vlastního hlavního města Prahy na rok 2014, dotačních vztahů k městským částem na rok 2014 a rozpočtového výhledu do roku 2019 (On the Proposal of Budget of the City of Prague for the Year 2014, of the Subsidy Relations to City Districts of the City of Prague for the Year 2014, and Budget Outlook till 2019). Prague: Prague City Assembly, 12 December 2013.

City of Prague (2013a). K návrhu na poskytnutí dotace městským částem hl. m. Prahy z finančních prostředků obdržených jako odvod z loterií dle ust. § 41i odst. 1 písm. b) zákona č. 202/1990 Sb., o loteriích a jiných podobných hrách v prüběhu ledna až dubna 2013 (On the Proposal to Allocate Subsidies to City Districts of Prague from the Financial Resources Obtained as the Tax from Lotteries According to Law no. 202/1990 Coll. on Lotteries and Other Similar Games for the Period January to April 2013). Prague: Prague City Assembly, 20 June 2013.

City of Prague (2013b). Obecně závazná vyhláška č. 20/2013, kterou se stanoví místa a čas, na kterých Ize provozovat loterie a jiné podobné hry, a kterou se stanoví opatření k omezení jejich propagace (Decree No. 20/2013 on Determining the Places and Time for Operating Lotteries and Similar Games and on Determining Measures to Limit their Marketing). City of Prague, 20 September 2013.

City of Prague (2014). K petici proti drogám, za přemístění služeb poskytujích substituční léčbu a poradenství pro drogově závislé (On the Petition against Drugs, for the Relocation of Services Providing Substitution Treatment and Counseling for Drug Addicts). Prague: Prague City Assembly, 24 April 2014.

City of Prague (2014a). Protidrogová politika hlavního města Prahy 2014 - 2020 (Drug Policy in the City of Prague 2014 - 2020). Prague: Prague City Assembly, 27 March 2014.

City of Prague (2014b). Akční plán protidrogové politiky hlavního města Prahy 2014 - 2016 (Action Plan of Drug Policy 2014 - 2016). Prague: Prague City Assembly, 11 September 2014.

City of Prague (2014c). Výroční zpráva o realizaci protidrogové politiky hlavního města Prahy 2013 (Annual Report on the Implementation of Drug Policy of the City of Prague 2013). Prague: Prague City Assembly, 11 September 2014.

City of Prague (2014d). Rozpracování principu spravedlivé distribuce nízkoprahových služeb na území hlavního města Prahy (Development of the Principle of Fair Distribution of Low-Threshold Services in the City of Prague). Prague: Prague City Assembly, 29 May 2014.

City of Prague (2014e). Zásady pro zřizování zón placeného stání na území hl. m. Prahy dle nové Koncepce rozvoje zón placeného stání na území hlavního města Prahy (Rules for Establishing Parking Zones in Prague according to the New Concept of Parking Policy on the Territory of the Capital City of Prague). Prague: Prague City Council, 9 September 2014.

City of Prague (2015). Rozpracování principu spravedlivé distribuce nízkoprahových služeb na území hlavniho města Prahy (Development of the Principle of Fair Distribution of Low-Threshold Services in the City of Prague). Prague: Prague City Assembly, 26 November 2015. 
Davis, C. (1986). Public Involvement in Hazardous Waste Siting Decisions. Polity, 19(2), 296-304, http://dx.doi.org/10.2307/3234916

Hager, C., Haddad, M. A. (Eds) (2015). NIMBY is Beautiful: Cases of Local Activism and Environmental Innovation around the World. New York and Oxford: Berghahn Books. ISBN: 978-1-78238-601-8.

Hall, R. H. (1981). Industrial Waste. The Globe and Mail, 5 January 1981, 6.

Johnson, T. (2013). The Health Factor in Anti-Waste Incinerator Campaigns in Beijing and Quanzhou. The China Quarterly, 214, 356-375, http://dx.doi.org/10.1017/ s0305741013000660

Kraft, M. E., Clary, B. B. (1991). Citizens Participation and the NIMBY Syndrome: Public Response to Radioactive Waste Disposal. The Western Political Quarterly, 44(2), 299-238, http://dx.doi.org/10.2307/448780

Kunreuther, H., Easterling, D. (1996). The Role of Compensation in Siting Hazardous Facilities. Journal of Policy Analysis and Management, 15(4), 601-622, http://dx.doi.org/10.1002/ (sici)1520-6688(199623)15:4<601::aid-pam6>3.0.c0;2-I

Lake, R. W. (1993). Rethinking NIMBY. Journal of the American Planning Association, 59(1), 87-93, http://dx.doi.org/10.1080/01944369308975847

Livezey, E. T. (1980). Hazardous Waste. The Christian Science Monitor, 6 November 1980. Available at: http://www.csmonitor.com/1980/1106/110653.html

Mas-Colell, A., Whinston, M. D., Green, J. R. (1995). Microeconomic Theory. Oxford: Oxford University Press. ISBN: 978-0195073409.

Mitchell, R. C., Carson, T. C. (1986). Property Rights, Protests, and the Siting of Hazardous Waste Facilities. American Economic Review, 76(2), 285-290. Available at: http://econweb.ucsd. edu/ rcarson/papers/Siting.pdf

Popper, F. J. (1992). The Great LULU Trading Game. Planning, 58(5), 15-17.

Rose, J. B. (1993). A Critical Assessment of New York City's Fair Share Criteria. Journal of the American Planning Association, 59(1), 97-100, http://dx.doi. org/10.1080/01944369308975849

Samuelson, P. A., Nordhaus, W. D. (1995). Economics, 15. Ed., New York: McGraw-Hill.

Weisberg, B. (1993). One City's Approach to NIMBY: How New York City Developed a Fair Share Siting Process. Journal of the American Planning Association, 59(1), 93-97, http://dx.doi.org/10.1080/01944369308975848

Wolsink, M. (2007). Wind Power Implementation: The Nature of Public Attitudes: Equity and Fairness Instead of Backyard Motives. Renewable and Sustainable Energy Reviews, 11(6), 1188-1207, http://dx.doi.org/10.1016/j.rser.2005.10.005 